\title{
14
}

\section{WHEN A CREDIBLE SOURCE TURNS 'FAKE'}

\section{The Relotius affair and the German system for combating fake news}

\author{
Mihail Stojanoski
}

\section{Introduction}

The term 'fake news' has been omnipresent in society, particularly in political discourse for several years. In spite of its popularity among political figureheads, journalists, and researchers (or, maybe exactly because of that), a unified definition of the term proves somewhat elusive. It is, of course, quite natural that a term as recent ${ }^{1}$ and controversial as 'fake news' should be used in a variety of (sometimes conflicting) ways, which is partly why academia cannot agree on a single definition. The Cambridge Dictionary defines 'fake news' as false stories that appear to be news, spread on the Internet or using other media, usually created to influence political views or as a joke. ${ }^{2}$ Another definition which takes different factors into account defines fake news as the deliberate presentation of (typically) false or misleading claims as news, where the claims are misleading by design (Gelfert 2018). There appear to be many definitions around, all of which take various aspects of the phenomenon into account, whether it is the presence of intent, the results, the environment where it emerges, or something else.

In any event, there appears to be common ground between the sources that measures need to be taken to impede, block, punish, or (better) prevent the spread of fake news. Although the risks and dangers which follow fake news are not a topic of central interest of this chapter, we would stress that one of the primary concerns of legislators seems to be elections, or rather information available to voters during election periods. This narrative follows the premise that decisions in times of elections are made on a personal level, on the basis of available information. Therefore, if the flow of information cannot be trusted, the whole democratic process, including the result, would be compromised. ${ }^{3}$

In this article, we will examine the recent German anti-fake-news law ('Gesetz zur Verbesserung der Rechtsdurchsetzung in sozialen Netzwerken, Netzdurchsetzunggesetz', or just 'NetzDG') in a very practical context. The whole 
idea surrounding the law, which takes a novel and unique approach, was built on the premise that the greatest risk for the flow of information comes from the spread of fake news on social media. These platforms have largely replaced traditional media to a large extent as the primary source of news. ${ }^{4}$ Meanwhile, operating under the assumption that they can generally be trusted, nobody thought to look at traditional media. And why would we? The occasional left or right leaning journalist is nothing that old democracies are not used to. The fearful finger was pointed at social media, and oh my, were we surprised.

However, in the defence of the lawmakers, given that the Relotius affair (the details of which will be presented below) may not even be considered as fake news at its most fundamental understanding, the affair presented somewhat of a sui generis challenge for the system, one which was difficult to anticipate. In these circumstances, the chapter touches on issues such as the limits of truth and fact checking, responsibility of the State vis-à-vis the individual in the field of free speech and the (practical and legal) limitations, which exist as to what can be achieved by legislating.

The chapter follows a two-pronged analysis, with an attempt at a synthesis of those two topics in a third, final section. At the outset, factual background is provided in order to explain the Relotius affair, its significance, and its consequences. Then, we will briefly analyse the new legal system aimed at combating hate speech and fake news in place in Germany as a starting point for any contextual analysis of the Relotius affair. Finally, the chapter attempts to reconcile the two ideas and develop some observations in that regard.

\section{The Relotius affair}

Claas Relotius is a German freelance reporter wrote for a number of Germanlanguage publications, including Cicero, Frankfurter Allgemeine Sonntagszeitung, Neue Zurcher Zeitung, Financial Times Deutschland, Die Tageszeitung, and Die Welt. Since 2017 he had been working as an editor for Der Spiegel (Der Spiegel 2018c). During his career he managed to collect an impressive number of awards, including CNN's journalist of the year (2014), the European Press Prize (2017), and the Deutscher Reporterpreis (four times, including 2018).

There is little need to introduce Der Spiegel. It is a Hamburg-based weekly news magazine with a circulation of around 740,000 copies, which in the past exceeded one million (European Publishing Monitor 2007). In addition, it has an estimated base of 6.5 million online readers (Connolly 2018). It is widely considered as one of the most influential news magazines in Germany and Europe, responsible for uncovering several scandals and affairs thanks to its pronounced and thorough investigative journalism (Strawn and Hogan 1984/1985). What became known as the Relotius affair can be described in the following way.

Since 2011, when his cooperation with the reputed magazine began, almost 60 articles written by Relotius were published by Der Spiegel magazine or Spiegel Online, its Internet counterpart. The articles reached a high audience, were widely 
regarded as top-notch journalism and can be directly linked to some of the awards listed above. Being an already successful journalist of a relatively young age, he was a rising star.

The first suspicions regarding the veracity of his articles emerged in November 2018 following the publication of the article entitled 'Jaeger's border' (Jaegers grenze') $)^{5}$ about an American vigilante group that patrolled the border between Mexico and the United States. Juan Moreno, who reported the story together with Relotius, was one of the first to grow distrustful of his colleague. He had raised suspicions about the work carried out by Relotius before the magazine's editors by late 2018, but his concerns were largely ignored.

Some at Der Spiegel even believed that Moreno was the real phony and that Relotius was the victim of slander. Relotius skilfully parried all allegations and all of Moreno's well-researched evidence, constantly coming up with new ways of sowing doubt, plausibly refuting accusations and twisting the truth in his favour (Fichtner 2018).

"At the start it was the small mistakes, things that seemed too hard to believe that made me suspicious." Moreno went on to describe how it had been strange that some of the protagonists in Relotius's articles had not wanted to be photographed, in spite of being already prominent in the US media. "At some point I just thought something is monumentally wrong here ... I started to do my own research only to discover that that [the same] protagonist [who had allegedly refused to be photographed] had already appeared in The New York Times," said Moreno. ${ }^{6}$

Relotius was eventually confronted by the magazine's management. By the beginning of December, facing a growing pile of evidence and distrust, he made a full confession. News of the affair was broken to the public on December 19th by Der Spiegel itself. According to the confession, at least 14 articles written by him were at least partly fabricated. ${ }^{7}$

Among the articles in question are major features that were nominated for or won journalism awards. For example, an article entitled 'The last witness', about an American who allegedly travels to witness an execution, is among the 14 articles. Another two, entitled 'The lion children', about two Iraqi children who have been kidnapped and re-educated by the Islamic State, and 'Number 440', a story about prisoners at Guantanamo, also fall within those which, according to the confession, contain falsities. In the stories, he included individuals who he had never met or spoken to, but he told their stories and quoted them. Instead of actually meeting them, he revealed that he had based the depictions on other media or video recordings. ${ }^{8}$ By doing so, sometimes he created composite characters based on several actual people, but whose stories he fabricated. He also made up entire lines of dialogue and quotes. ${ }^{9}$

As to Relotius's reasons for fabricating the articles, before handing in his resignation, he said: "It wasn't about the next big thing. It was the fear of failure. The pressure not to fail grew as I became more successful" (Fichtner 2018). 
Following the revelation, Der Spiegel publicly apologised to its readers and undertook to conduct a thorough investigation. They called it "the lowest point in the 70-year history of Der Spiegel" (ibid.). They created a three-member expert commission that was tasked to evaluate the damage and to find ways to prevent similar incidents from happening in the future. ${ }^{10}$

The outcry in the wake of these events was enormous. The German Federation of Journalists called the case "the biggest fraud scandal in journalism since the Hitler diaries," referring to a story that Germany's Stern magazine published in 1983, which was later proven to be fake. ${ }^{11}$

For the moment, all the articles written by Relotius remain publicly available on the website of the magazine, with a notification about the scandal added for clarity. As argued, they did it to provide the possibility for transparent research on the issue (Der Spiegel 2018c).

As a final touch, Der Spiegel announced that they would file criminal charges against Relotius for fraud with regard to donations collected in the name of Syrian orphans, featured in one of his articles (Klusmann 2019). As alleged, he collected donations from concerned readers claiming that the money would be used with the aim of helping these children, but the money eventually ended up in his own bank account.

Relotius remained silent following the outbreak of the affair, avoiding public appearances. However, on 27 December 2018 in response to the claims made regarding the alleged fraud, he admitted through his attorneys that the donations were made to his bank account, but he claimed that he had never intended to keep the money. He had collected 7000 euros from readers, to which he added 2000 euros of his own and made a donation to a relief agency. The agency in question, when contacted by Der Spiegel, confirmed that a donation of the above amount had been made by Relotius in October 2016 (ibid.). The proceedings are ongoing.

At the moment of writing and according to the available information, apart from breaking his relationship with Der Spiegel, there is no indication of any sanctions or proceedings against Relotius specifically regarding the falsities contained in his articles.

\section{The regulation of disinformation in Germany}

A recently conducted census representative survey by Dalia Research found that $34 \%$ of Germans using social media have read articles or news that were intentionally misleading or not truthful (fake news), 16\% have received offensive messages or comments from someone they do not know, 14\% have received sexually offensive messages, and 3\% have received threats. $16 \%$ of Germans have also reported a user for abuse on social media (Dalia Research 2018). Although the survey is based on self-reporting, the results are worrisome.

Before the introduction of the NetzDG, disinformation was dealt with under the existing legislation. Although spreading disinformation was not a crime per se, hate 
speech was prohibited and regulated in Section 130 of the German Criminal Code (listed as 'Incitement to hatred'), and provided for imprisonment up to five years.

In this regard, the provisions of the EU e-commerce Directive adopted in $2000^{12}$ should be mentioned. The directive prescribes liability for social media that would host illegal content, unless they can prove that they have no actual knowledge of, or act promptly to remove or disable access to the content in question.

Recognising a threat in the effect that fake news may have on elections, on 30 June 2017, three months before the federal elections, the German parliament adopted a law targeting specifically hate speech and fake news, which some consider the most extreme reaction to disinformation among Western countries (Cerulus 2017). The danger of fake news affecting election results, following the 2016 election campaign in the United States, was explicitly referred to in the government's reasoning justifying the need for the new law (NetzDG draft bill 2017: 1). As earlier efforts to curb hate speech had been considered ineffective by the German Minister Heiko Maas (ibid.), the primary objective of the new law was to improve the otherwise insufficient regulation of the spread of hate speech online. Then Justice Minister (and current Foreign Minister) Heiko Maas presented it as a means to tackle online hate speech and viral deception: "The freedom of expression also protects offensive and hateful statements. But it is not an excuse to commit crimes" (Der Spiegel 2018a).

Under the so-called Network Enforcement Act (NetzDG), which came into effect on 1 January 2018, Germany introduced new obligations for social networks aimed at combating hate speech and fake news.

Among these, social networks with at least two million registered users in Germany are obliged to create and maintain a procedure for complaints with regard to "unlawful content" 13 which is defined as content meeting the elements of certain provisions of the German Criminal Code. Among other provisions the NetzDG here makes reference to sections $\$ 166$ (Defamation of religions, religious and ideological associations), $\$ 185$ (Insult), $\$ 186$ (Defamation), and $\$ 187$ (Intentional defamation). The Act further makes a distinction between "unlawful" and "manifestly unlawful" content, ${ }^{14}$ which remains somewhat unclear. In any event, social networks are required to remove or block access to the impugned content within either seven days or 24 hours of the user's complaint.

Social media are required to decide on the compliance of content with the above Criminal Code sections themselves, or externalise the decision to an independent third party, essentially granting them a quasi-judicial role. It should be noted that fines for social media are only envisaged for systemic non-compliance with the requirements, and not on a case-by-case basis.

Critics of the new law attacked it for surrendering the control over important social issues to private companies. The key concern revolved around the argument that in order to avoid being fined, social media would apply a "take down first, examine later' policy, which would in turn have a chilling effect on free speech. 
TABLE 14.1 Number of reports of fake news and removal rate

\begin{tabular}{lcr}
\hline Social network & Total no. of reports & \multicolumn{1}{c}{ Removal rate } \\
\hline Facebook & 1704 & $362(21.2 \%)$ \\
Google (YouTube) & 241,827 & $58,297(27.1 \%)$ \\
Twitter & 264,818 & $28,645(10.8 \%)$ \\
Change.org & 1257 & $332(26.4 \%)$ \\
\hline
\end{tabular}

The most relevant feature of the NetzDG for this chapter is that journalistic and editorial content were explicitly removed from its scope. ${ }^{15}$ This means that online news portals, online magazines, journalistic platforms, and the like are not to be treated identically with social media. These fall outside the scope of the NetzDG and remain regulated under the existing legislative framework.

The effects of the NetzDG were immediate. On 1 January 2018, the day that the NetzDG came into effect, Twitter and Facebook removed a post from a German far-right politician who accused the Cologne police (who had tweeted a new year message in Arabic) of appeasing "barbaric, gang-raping Muslim hordes of men" (Oltermann and Collins 2018).

When it comes to EU monitoring of unlawful online content and its removal in Germany, in January 2018 the Commission reported that "companies have strengthened their reporting systems, making it easier to report hate speech, and have improved their transparency vis-à-vis [. . .] users in general". Subsequent rounds of EU monitoring demonstrated steady improvements in content removal rates across the EU. In Germany, the average rate of removals for Facebook, Twitter, and YouTube combined went from 52\% in December 2016 to $100 \%$ in the third monitoring exercise the following year (Echikson and Knodt 2018). It should be noted, however, that this $100 \%$ figure, although somewhat concerning, in practice refers to a little over 200 pieces of content taken down pursuant to requests made by two accredited German flaggers, who are at the origin of this data (ibid.).

Since the above events, blocks and removals under the NetzDG have failed to draw significant media attention. As far as it could be established, there have been no reports of controversial false positives, and no fines for the social media providers have been imposed under the law. The total reports and removals for the first six months from the four social networks currently affected under the NetzDG are shown in Table 14.1 (ibid.).

\section{Conclusion}

For more than a year, the selfie of a Syrian refugee with Angela Merkel has been coursing through the social networks, combined with the lie that the refugee in question was an Islamic State assassin. The person in question has sued Facebook and the original photo montages have been eventually deleted. In spite of this, a 
number of people will nevertheless remember an image of Angela Merkel posing with a terrorist (Beuth et al. 2017). Similar reports can be found everywhere and they cause great harm, with the reputation of public persons and politicians being at the front line of fire.

Initial results of the implementation of the NetzDG testify that there is very little evidence of mass take-downs of content (see Table 14.1). The German courts have already had time to produce case-law on the application of the NetzDG, which, although not entirely coherent at the moment, underlines the complexity of the issue. ${ }^{16}$ It should also be said that the removals concerning defamation and insult make for around 19\% of the total removals done by Google for the first six months of the application of the NetzDG. Furthermore, 75\% of these were removed under Google's community guidelines, which means that they would have been removed in spite of NetzDG. ${ }^{17}$

Getting back to the Relotius affair, it would seem that, given the explicit exclusion of journalistic content from the scope of the NetzDG, the Act would simply not apply in this case. The criminal charges for fraud (which are not a direct consequence of his false reporting) cannot lead to a different conclusion.

On a side note (and with some irony), it would appear that the NetzDG's scope would extend to the articles in question, had any of them (or conclusions based on them) been shared on social media.

Given the above, questions arise as to the effectiveness and level of protection against falsities under the current German legislation. If we take a look at comparable legislation in neighbouring France, ${ }^{18}$ it should be noted that the French legislative reform brought online platforms (including journalistic platforms and social media) under the already existing obligation of the Consumers Code to make any financial links, sponsorship, or contractual obligations with regard to content public. ${ }^{19}$ Further to this, new interlocutory proceedings were introduced where a judge can order any proportionate and necessary measure against Internet service providers and hosts to stop the spread of fake news. ${ }^{20}$

Observing the above measures one cannot but note that much like its German counterpart, the French legislation also addresses fake news in a responsive manner. Neither Germany nor France have enacted legislation which aims at preventing the appearance of fake news or strengthening media literacy. ${ }^{21}$

Could the French model have suppressed the fraudulent articles published by Relotius? Doubtful. Analysis of further models, such as the one proposed in the United States, or the one in force in Russia, do not reveal an alternative approach that could have prevented an event such as the Relotius affair.

It is beyond doubt that the harm caused by Relotius's articles is serious and significant, to the point that it may have shaped the opinion of readers and individuals in ways that we cannot begin to comprehend. How did the articles shape long-term societal values, political views, and by extension, election results? At this point we can only speculate that the damage is at least comparable to the one caused by articles such as the ones which fit the prima facie definition of fake news, presented at the beginning of this chapter. ${ }^{22}$ 
If the damage is significant and the existing legislation does not cover the example at hand, is this something which can be solved by further regulation? Most likely, not. What is the solution, then?

Der Spiegel has one of the most advanced and dedicated fact-checking systems in Europe (Southern 2017), which can only serve to testify as to the dedication of the magazine to truthful reporting, but that did not help them in preventing the Relotius incident. This is primarily due to the nature of the articles that the reporter wrote, the fact that he intentionally covered his tracks, but also the nature of investigative journalism in general. To put it simply, what a Syrian child said to a foreign reporter in a dusty alley in a small town in eastern Turkey is simply beyond the scope of fact-checking as such. However, some facts that were clear fabrications and could be fact-checked (for example, some of the facts surrounding the article 'Jaeger's border' described above), were the ones that led to Relotius's downfall. So, the obvious, inherent limitations to fact-checking as a process should not discourage society's pursuit for responsible journalism, and by extension, truth. Should we simply come to terms with the fact that embellishing, misrepresenting, and even straight out fabrications are inherent to journalism? Can Der Spiegel be blamed for their failure? Not unless we put our finger on where they failed. And it seems that they did an excellent job at dotting all of their i's and still let a big one slip through.

Responsible journalism cannot be regulated any more than it already is without infringing on the freedom of expression. This is why the ultimate responsibility lies with the news consumers themselves. They (or, rather, 'we') need to be aware that the system of news reporting and journalism is essentially dependent on a human element, and is therefore bound to inherit human imperfections as such. The alternative would be a completely regulated flow of information and filtered truth, and although that did not happen in 1984 as some had anticipated, the risks are very much present today.

\section{Notes}

1 The term is somewhat recent. The concept, some would argue, is hundreds of years old. To this end see: Sol (2016).

2 https://dictionary.cambridge.org/dictionary/english/fake-news.

3 Some examples capable of influencing the outcome of elections include the allegations that German soldiers had raped a young girl during a NATO operation in Lithuania, that NATO had put 3600 tanks into position against Russia, that 700,000 Germans had left their homes because of Angela Merkel's refugee policies, or that 1000 immigrants had lit a church in Dortmund on fire. Needless to say, none of these are true. For these and other examples, see Beuth et al. (2017).

4 For example, around $20 \%$ of adults in the United States stated that they "get news often" through social media. See Perez (2018).

5 The article was, of course, published in German. Some argue that this, along with his reluctance to have his work translated into other languages was deliberate, as the language gap between his readers and his interviewees, who were mostly foreign, made it easier for him to maintain the deception. See: Slyomovics (2018).

6 Statements from a video released by Juan Moreno, cited by the Guardian in Connolly (2018). For more, see: Carbajosa (2019). 
7 Der Spiegel has since provided ample information on the development of the case (Der Spiegel 2018c). As the affair develops, further information is made available by the magazine itself, which is now attempting to rebuild its former reputation by taking responsibility and dealing with the affair head on.

8 For example, in one of his earlier articles Relotius wrote about an American town called Fergus Falls. In his article he wrote that the movie American Sniper had been running in the local cinema for two years consecutively, at the entrance to the town there had been a sign saying 'Mexicans Keep Out', a school was protected with a metal detector and three armoured glass doors, and much more. All of this was eventually established to be false.

9 Sources are various articles published by Der Spiegel following the affair, all of which are cited in the References.

10 For more information on the commission and its composition, see: Der Spiegel (2018b).

11 The diaries were later found to be forgeries (Sharman 2018).

12 It is the Directive 2000/31/EC, Directive on electronic commerce, available at: https:// eur-lex.europa.eu/legal-content/EN/ALL/?uri=CELEX\%3A32000L0031.

13 See Section 3, paragraph 1 of the Act. An official English version of the NetzDG 'Act to Improve Enforcement of the Law in Social Networks (Network Enforcement Act) - is available on the German Ministry of Justice website, at: https://www.bmjv.de/ SharedDocs/Gesetzgebungsverfahren/Dokumente/NetzDG_engl.pdf?__blob= publicationFile\& $\mathrm{v}=2$

14 The wording used in German is "offensichtlich rechtswidrigen Inhalt". The distinction between the two appears to be of crucial importance and, up to the point of writing, nothing to clarify this issue has been made available by the government. The NGO Article 19 has been particularly critical of this (Article 19 2017:19).

15 This is clear from the outstart of the approved text: see Article 1, paragraph 1 (1).

16 A few examples are provided in Echikson and Knodt (2018), p.11.

17 Not all social media platforms submitted detailed reports on their activities under the NetzDG specifically as to the heading under which the content was removed. That is why the analysis is limited to Google (which includes Google+ andYou Tube), which was a rare example of providing pondered data by sections of the Criminal Code. It should be noted that although the obligation to submit such reports stems from the NetzDG, the level of detail of the data in those reports is not specifically prescribed.Therefore, it could be said that Google exceeded the requirements of the law in this regard.

18 'Loi relative à la lutte contre les fausses informations', No. 799, Article 1, inserting Article L. 163-2 in the French Electoral Code, from 2018.

19 Code de la consommation - Article L111-7, paragraph 2, subparagraph 2

20 The list of measures presented here is not exhaustive.

21 This conclusion is, of course, notwithstanding any ongoing campaigns for media literacy which are not strictly the consequence of the laws in question. Such campaigns were promoted by several journalistic associations and NGOs, which is a topic better left for another time.

22 See note 4 above. At this point it appears important whether the current definitions of 'fake news' may or may not cover the articles written by Relotius. There are several elements that need to be taken into account before a final decision is reached on this issue, such as the existence of intent, the effect, the medium where the news was published, to name just a few. Every country, in line with its margin of appreciation, will decide on a definition. In any event, reaching a decision on this point is not the aim of this chapter.

\section{References}

Article 19 (2017) 'Germany: The act to improve enforcement of the law in social networks', August 2017, www.article19.org/wp-content/uploads/2017/09/170901-Legal-AnalysisGerman-NetzDG-Act.pdf (last consulted 1 August 2019). 
Bekämpfung von Hasskriminalität und strafbaren Falschnachrichten (2017) 'Bessere Rechtsdurchsetzung in sozialen Netzwerken', www.fair-im-netz.de/SharedDocs/Artikel/DE/ 2017/03142017_GE_Rechtsdurchsetzung_Soziale_Netzwerke.html;jsessionid=74F939 C38342BBB7AAC3333C69FB82CF.1_cid289 (last consulted on 20 April 2019).

Beuth, P., M. Brost, P. Dausend, S. Dobbert, G. Hamann, (2017) 'War without blood', Zeit, 26 February 2017, www.zeit.de/digital/internet/2017-02/bundestag-elections-fakenews-manipulation-russia-hacker-cyberwar (last consulted on 22 August 2019).

Carbajosa, A. (2019) 'How a Spanish journalist unmasked the "Der Spiegel" forgery scandal', El Pais, 1 March 2019, https://english.elpais.com/elpais/2019/02/26/inenglish/ 1551176169_246969.html (last consulted on 25 August 2020).

Connolly, K. (2018) 'Der Spiegel reporter who faked stories returns awards', The Guardian, 21 December 2018, www.theguardian.com/world/2018/dec/21/sacked-der-spiegelreporter-claas-relotius-returns-awards (last consulted on 25 August 2019).

Cerulus, L. (2017) 'Germany's anti-fake news lab yields mixed results', Politico [interactive], www.politico.eu/article/fake-news-germany-elections-facebook-mark-zuckerbergcorrectiv (last consulted on 17 April 2019).

Dalia Research (2018) '87\% of Germans approve of social media regulation law', 17 April 2018, https://daliaresearch.com/blog-germans-approve-of-social-media-regulation-law/ (last consulted 19 April 2019).

Der Spiegel (2018a) 'Maas verteidigt Gesetz gegen Hass im Internet', 4 January 2018, www.spiegel.de/netzwelt/netzpolitik/netzdg-heiko-maas-verteidigt-netzwerkdurch setzungsgesetz-gegen-kritik-a-1186118.html (last consulted on 9 September 2019).

Der Spiegel (2018b) 'Kommission aus erfahrenen Journalisten soll Routinen beim SPIEGEL hinterfragen', 19 December 2018, www.spiegel.de/kultur/gesellschaft/der-fall-claasrelotius-wie-der-spiegel-auf-die-faelschungen-reagiert-a-1244569.html (last consulted on 15 April 2019).

Der Spiegel (2018c) 'The Relotius case - Answers to the most important questions', 19 December 2018, www.spiegel.de/international/the-relotius-case-answers-to-the-mostimportant-questions-a-1244653.html (last consulted on 1 August 2019).

DW (2018) Der Spiegel files suit against ex-star reporter Claas Relotius', 23 December 2018, www.dw.com/en/der-spiegel-files-suit-against-ex-star-reporter-claas-relotius/a46849218(last consulted on 16 August 2019).

Echikson, W., O. Knodt (2018) 'Germany's NetzDG: A key test for combating online hate', CEPS Research Report No. 2018/09, www.ceps.eu/publications/germany $\%$ E2\%80\%99snetzdg-key-test-combatting-online-hate (last consulted 19 April 2019).

European Publishing Monitor (2007) Germany, Media Group Turku School of Economics, March 2007, http://edz.bib.uni-mannheim.de/daten/edz-du/gda/07/med-ind-germany_ en.pdf (last consulted on 1 April 2019).

Fichtner, U. (2018) Der Spiegel reveals internal fraud', Der Spiegel, 20 December 2018, www.spiegel.de/international/zeitgeist/claas-relotius-reporter-forgery-scandal-a1244755.html (last consulted on 13 August 2019).

Gelfert, A. (2018) 'Fake news: A definition', Informal Logic 38(1): 84-117, https://informallogic. ca/index.php/informal_logic/article/view/5068/4350 (last consulted on 22 April 2019).

German Ministry of Justice (2017) 'NetzDG draft bill prepared by the Federal Ministry of Justice and Consumer Protection', draft version of 27 March 2017, www.gesetze-iminternet.de/englisch_stgb/englisch_stgb.html (last consulted on 25 August 2020).

Human Rights Watch (2018) 'Germany: Flawed social media law', 14 February 2018, www.hrw.org/news/2018/02/14/germany-flawed-social-media-law (last consulted on 17 April 2019). 
Klusmann, S. (2019) 'The lessons we are drawing', Der Spiegel, 7 January 2019, www.spiegel. de/international/claas-relotius-affair-the-lessons-we-are-drawing-a-1246823.html (last consulted on 17 August 2019).

NetzDG Draft Bill (2017) 'Entwurf eines Gesetzes zur Änderung des Netzwerkdurchsetzungsgesetzes', German Government, text in Germany available at: www.bmjv.de/SharedDocs/ Gesetzgebungsverfahren/Dokumente/RegE_Aenderung_NetzDG.pdf;jsessionid=D89 52A9C53BA2715E7C504D2C0BE7A44.2_cid297?_blob=publicationFile\&v=2.

Oltermann, P., P. Collins (2018) 'Two members of Germany's far-right party investigated by state prosecutor', The Guardian, 2 January 2018, www.theguardian.com/world/2018/ jan/02/german-far-right-mp-investigated-anti-muslim-social-media-posts (last consulted on 12 April 2019).

Perez, S. (2018) 'PEW: Social media for the first time tops newspapers as a news source for US adults, Tech Crunch, https://techcrunch.com/2018/12/10/pew-social-mediafor-the-first-time-tops-newspapers-as-a-news-source-for-u-s-adults (last consulted on 19 July 2019).

Sharman, J. (2018) 'Award-winning journalist at Der Spiegel admits making up stories including interview with Colin Kaepernick's parents', The Independent, 20 December 2018, www.independent.co.uk/news/world/europe/der-spiegel-reporter-fake-storiesclaas-relotius-journalist-made-up-interviews-fabricated-a8692006.html (last consulted on 16 August 2019).

Slyomovics, N. (2018) Der Spiegel reporter who faked his stories isn't the real problem', Haaretz, 27 December 2018, www.haaretz.com/us-news/.premium-der-spiegelreporter-who-faked-his-stories-isn-t-the-real-problem-1.6787453 (last consulted on 22 April 2019).

Sol, J. (2016) 'The long and brutal history of fake news', POLITICO Magazine, 18 December 2016, http://politi.co/2FaV5W9 (last consulted on 2 August 2019).

Southern, L. (2017) 'Inside Spiegel's 70-person fact-checking team', Digiday UK, 15 August 2017, https://digiday.com/media/inside-spiegels-70-person-fact-checking-team/ (last consulted on 22 August 2019).

Strawn, J., C. G. Hogan (1984/1985) 'Democracy on the take, Flick scandal shakes West German politics', The Multinational Monitor 12(6), awww.multinationalmonitor.org/ hyper/issues/1984/12/strawn.html (last consulted on 19 April 2019).

Sullivan, M. (2013) 'Repairing the credibility cracks', The New York Times, 4 May 2013, www.nytimes.com/2013/05/05/public-editor/repairing-the-credibility-cracks-afterjayson-blair.html (last consulted on 3 April 2019).

The Cambridge Dictionary Online, 'Fake news', https://dictionary.cambridge.org/dictionary/ english/fake-news (last consulted on 25 August 2019). 